\title{
22. PETROGRAPHY OF OPAQUE MINERALS, LEG 34
}

\author{
James M. Ade-Hall, Department of Geology, Dalhousie University, Halifax, Nova Scotia, Canada \\ L. Kenneth Fink, Ira C. Darling Center for Research, University of Maine, Walpole, Maine \\ and \\ Harlan Paul Johnson, CIRES, P.S.R.B. No. 1, University of Colorado, Boulder, Colorado
}

\section{INTRODUCTION}

The opaque phases of basaltic rocks have received intensive study during the last decade in an attempt to test the implications and reliability of paleomagnetic results. Most attention has been given to the alteration of the usually dominant titanomagnetite, since the type and degree of alteration strongly affect magnetic properties. Various types of alteration have been identified and classification schemes devised. High temperature or deuteric oxidation state is classified into six stages of increasing degree of oxidation (Wilson et al., 1968; AdeHall et al., 1968). Low temperature alteration, at least where associated with zeolite facies metamorphism, also produces a range of mineralogical and magnetic changes (Ade-Hall et al., 1971). Submarine lavas frequently show similar magnetic properties to zeolite facies subaerial basalts, but the fine grain size of much of the pillow basalt material studied has often precluded identification of the nature of titanomagnetite alteration. Drilling into oceanic basement, with the anticipation of recovery of coarse-grained massive basalt and intrusive material should provide the opportunity to study the alteration of titanomagnetite resulting from the halmyrolysis and, perhaps, zeolite facies metamorphism in the oceanic crust.

During Leg 34, 105 meters of basalt were cored at three sites in the Nazca plate, with a recovery of 15 meters, much of it consisting of massive coarse-grained basalt. This chapter describes the opaque mineralogy of 40 Leg 34 basalt samples, together with four samples of basalt from Site 157 of Leg 16, the only other Nazca plate DSDP site. A wide range of opaque phases, including alteration products, occur in these samples. Several important new results are described in this chapter. These relate both to the opaque phases themselves and to their relationship to the magnetic properties of the basalts (as described in Ade-Hall et al., Rock Magnetism of Basalts, this volume).

\section{EXPERIMENTAL METHOD}

Both shipboard and shore microscope observations were made using Reichert Zeto-Pan Pol polarizing microscopes fitted with Polaroid and $35-\mathrm{mm}$ cameras and with automatic exposure meter systems. All opaque phase colors given here are as seen by one of us (AdeHall) using the Reichert microscope with a $\times 90$ oil immersion objective and without filters. A low-power zirconium light source was used throughout. Color description is subjective and we plan shortly to improve the color terminology with the aid of a microspectro- photometer and interlaboratory standards. On the ship it was possible to observe and photograph with highspeed Polaroid film successfully at magnifications of up to 525 diameters, the highest available at the time. Shore descriptive observations and most of the photography were carried out at Dalhousie University using an oil immersion objective and a total magnification of 1375 diameters. The higher magnification and better color control afforded by the oil immersion objective were essential factors in detecting significant but minor differences between the magnetites of different samples. Opaque phase content and grain-size measurements were made at the University of Maine using a Zeiss microscope. Important chemical and magnetic comparative information was obtained at Dalhousie University using a Cambridge Mark IV electron probe microanalyzer and a Curie balance based on a Cahn R100 recording electrobalance (see Ade-Hall et al., Rock Magnetism of Basalts, this volume, for details of the chemical and magnetic measurements).

\section{RESULTS}

Table 1 gives details of the opaque mineralogy of each sample, and Figures 1 to 21 illustrate typical and significant features. (The white bar on each figure is $25 \mu$ long.)

In this section each of the opaque phases present and alteration states are first described, followed by subsections dealing with specific topics such as the relationships between observed titanomagnetite alteration state and degree of cation deficiency as obtained from magnetic measurements.

\section{Petrography of Opaque Phases}

\section{Titanomagnetite}

In every sample high titanium content titanomagnetite was the most abundant opaque phase formed during initial crystallization. The composition of this titanomagnetite is known from rock magnetic and microprobe results to be close to $0.4 \mathrm{Fe}_{3} \mathrm{O}_{4} 0.6 \mathrm{Fe}_{2} \mathrm{TiO}_{4}$ for the basalts of Sites 319 and 321. It is reasonable to assume that the Site 157 and 320 basalts also crystallized titanomagnetites of close to this composition since this value falls within the closely confined range found for subaerial and other submarine oceanic basalts (Creer and Ibbetson, 1970; Ade-Hall et al., 1971). Most commonly, this titanomagnetite crystallized with skeletal form, indicating rapid cooling or quenching of the liquid basalt (Figure 1), but in the more massive basalts the arrested evolution of skeletal to anhedral or subhedral forms is commonplace (Figures 2 and 3). In some 
TABLE 1

Opaque Mineralogy of DSDP Basalts From the Nazca Plate

\begin{tabular}{ccc}
\hline Sample \\
$($ Interval in $\mathrm{cm})$
\end{tabular}$\quad \begin{array}{cc}\text { Description, Grain Size, Content (\% by volume) } \\
\text { Titanomagnetite }^{\mathrm{a}}\end{array}$

319-13-1, piece $2 \quad \begin{aligned} & \text { Skeletal to anhedral from } 10 \mu \text { down to the limit } \\ & \text { of visibility }\end{aligned}$

319-13-1, 75-78 $(1,2) \quad$ Skeletal or anhedral; larger grains bright gray with mottling, others with hematite or iron hydroxide rims; some red staining near oxides; $5.4 \mu, 0.21$,-

319-13-1, 108-111 (2) Skeletal; varying shades of color; some mottling and appear oxidized; some red staining of groundmass near opaque grains; $7.0 \mu, 0.30,1.1$

319-13-1, 140-143 (4) Skeletal; varying shades of color; some mottled altered ferromagnesians contain hematite or iron hydroxide

319-13, CC (polished Seven small chips; six contain homogeneous grains thin section TS1) at $10 \mu$; one contains $7.5-40 \mu$ skeletal to anhedral homogeneous grains; altered olivines may contain finally disseminated hematite or iron hydroxide

319-13, CC (polished thin section TS2)

319-13, CC (polished thin section TS3)

319A-1-1, 14-17 (1)

319A-1-1, 39-42 (2)

319A-2-1, 106-109 (1) Anhedral grains showing growth from a skeletal form, sometimes fringed with a second fine generation; either homogeneous or, less commonly, with expansion cracks and a little red staining of the surrounding silicates; $15 \mu, 2.5,1.9$

319A-2-1, 140-143 Complex mineralogy of this sample is described (split inner core)

319A-2-1, 146-149 (2) in detail in text

Skeletal to anhedral grains showing some expansion cracks and peripheral mottling; fine fringing generation on some of the larger grains; $18 \mu$, 2.7, 3.9

319A-3-2, 108-111 (1) Skeletal and anhedral grains containing occasionally a few ilmenite lamellae (deuteric oxidation class 2) and commonly, in certain areas, branching patterns or areas of a dull gray alteration product associated with expansion cracks; $26 \mu, 2.6,3.4$

319A-3-2, 108-111 (2) Skeletal to anhedral grains with corroded partly replaced margins, expansion cracks, and high reflectivity; red staining of the surrounding silicates occurs

319A-3-5, 81-84 (2) Large size anhedral to subhedral and small size skeletal grains, the latter sometimes fringing the former; some grains show expansion cracks but most grains are homogeneous and unaltered; $20 \mu, 2.6,2.9$

319A-4-1, 113-136 (2) Skeletal to anhedral form, rare expansion cracks the only indication of alteration; $18 \mu, 2.1,3.4$
Indet., ranging in size from $25 \mu$ to the limit of visibility

Occasional tiny indet. grains; $2.0 \mu$, 0.02

Occasional small indet. grains; Iron hydroxide; $2.1 \mu, \quad 0.01$

Occasional small indet. grains, $\leqslant 5 \mu$

No record

Chrome-aluminum spinel

Occasional indet. small grains; $6.4 \mu$, 0.01

Occasional indet. small grains; $20 \mu$, 0.02

Occasional small grains; Pyrite and rarer grains with chalcopyrite lamellae in a pyrrhotite base; $35 \mu$, 0.02

Occasional primary sulfides in fresh gray basalt; secondary veins and grains in dark-green altered basalt; $4.9 \mu, 0.24$

Rare small indet. grains; $10 \mu, 0.01$

Rare small indet. grains

Euhedral and anhedral forms; pyrite with an occasional grain with chalcopyrite in a pyrrhotite base; $4.5 \mu, 0.20$

Euhedral to anhedral grains of up to $30 \mu$ are abundant; pyrite, pyrrhotite; dark magnetite rims on some sulphides; $6.3 \mu, 0.20$ of polycrystalline
Occasional masses hematite or iron hydroxide in areas of altered silicates ilmenite, $70.2 \mu$, $0.015 \%$

Little anhedral ilmenite; 8.6, 0.25

Ilmenite; $21 \mu, 0.06$

Occasional masses of poorly crystallized dull hematite or iron hydroxide in areas of altered silicates; uncommon euhedral ilmenite; $23 \mu, 0.26$

Ilmenite; 8.0, 0.07

Little euhedral ilmenite; $14 \mu, 0.27$ 
TABLE 1 - Continued

\begin{tabular}{|c|c|c|c|}
\hline \multirow{2}{*}{$\begin{array}{c}\text { Sample } \\
\text { (Interval in } \mathrm{cm} \text { ) }\end{array}$} & \multicolumn{2}{|c|}{ Description, Grain Size, Content (\% by volume) } & \multirow[b]{2}{*}{ Other Phases } \\
\hline & Titanomagnetite $^{\mathrm{a}}$ & Sulphides & \\
\hline $319 A-4-1,141-144(2)$ & $\begin{array}{l}\text { Skeletal to anhedral form; appears completely } \\
\text { unaltered; } 17 \mu, 2.9,3.6\end{array}$ & $\begin{array}{l}\text { Abundant } 10 \mu \text { to } 20 \mu \text { grains, some } \\
\text { phase split, } 4.1 \mu, 0.32\end{array}$ & Ilmenite; $12 \mu, 0.13$ \\
\hline $319 A-5-1,72-75(2)$ & $\begin{array}{l}\text { Skeletal to subhedral form; appears completely } \\
\text { unaltered; } 23 \mu, 3.2,3.4\end{array}$ & $\begin{array}{l}\text { Abundant grains, some consisting } \\
\text { of two phases and others rimmed } \\
\text { with a dark magnetite; } 6.2 \mu, 0.35\end{array}$ & Ilmenite; $16 \mu, 0.04$ \\
\hline $319 A-5-1,87-90(2)$ & $\begin{array}{l}\text { Skeletal to anhedral form; rare expansion cracks } \\
\text { are only signs of alteration; } 17 \mu, 2.5,3.9\end{array}$ & $\begin{array}{l}\text { Sulfides relatively common; } 4.7 \mu \text {, } \\
0.21\end{array}$ & $\begin{array}{l}\text { Rare euhedral } \\
\text { ilmenite; } 5.5 \mu, 0.12\end{array}$ \\
\hline $319 A-6-1,142-145(2)$ & $\begin{array}{l}\text { Fine skeletal grains with higher reflectivity than in } \\
\text { unaltered samples; no iron migration into sur- } \\
\text { rounding silicates; } 3.1 \mu, 1.5,1.7\end{array}$ & $\begin{array}{l}\text { Rare small indet. sulfides of } 3 \mu \text {; } \\
-,<0.01\end{array}$ & Ilmenite; $3.1 \mu,<0.01$ \\
\hline $319 A-7-1,40-43(1)$ & $\begin{array}{l}\text { Skeletal to subhedral form; heightened reflectivity } \\
\text { and expansion cracks ty pical; mottling and mi- } \\
\text { gration of iron into the adjoining silicates not } \\
\text { present; } 4.8 \mu, 2.2,1.8\end{array}$ & $\begin{array}{l}\text { Occasional small }(5 \mu) \text { grains; } 2.0 \mu \text {, } \\
0.01\end{array}$ &,$-<0.01$ \\
\hline $319 A-7-1,116-119(2)$ & No data & & \\
\hline 320B-3-1, 76-79 (1) & $\begin{array}{l}\text { Extremely small skeletal grains, the larger showing } \\
\text { mottling, heightened reflectivity, and expansion } \\
\text { cracks; } 1.6 \mu, 0.7,-\end{array}$ & & \\
\hline $320 \mathrm{~B}-3-1,76-79(2)$ & $\begin{array}{l}\text { Extremely small skeletal grains, too small to dis- } \\
\text { tinguish color, internal features; groundmass sili- } \\
\text { cates strongly stained red-brown }\end{array}$ & Few very small indet. grains & \\
\hline $320 \mathrm{~B}-4-1, \quad 90-93 \quad(2)$ & $\begin{array}{l}\text { Skeletal grains showing color mottling or height- } \\
\text { ened reflectivity; } 3.5 \mu, 1.7,-\end{array}$ & Rare small indet. grains & $\begin{array}{l}\text { Occasional masses } \\
\text { of dull colored } \\
\text { hematite or iron } \\
\text { hydroxide in areas } \\
\text { of altered basalt }\end{array}$ \\
\hline $320 \mathrm{~B}-4-1,144-147(2)$ & $\begin{array}{l}\text { Skeletal grains, showing mottling, expansion } \\
\text { cracks, and corrosion, with red staining of the } \\
\text { surrounding silicates; } 6.1 \mu, 1.1,-\end{array}$ & Some very small grains; $(2 \mu$ to $4 \mu)$ & $\begin{array}{l}\text { Occasional hematite } \\
\text { or iron hydroxide } \\
\text { masses in vesicles; } \\
\text { rare isolated small } \\
\text { laths of ilmenite; } \\
(6.5 \mu, 0.4)\end{array}$ \\
\hline 320B-5-1, 108-113 (2) & $\begin{array}{l}\text { Highly altered skeletal grains in light colored ba- } \\
\text { salt, with high reflectivity, mottling, and in the } \\
\text { larger grains, many expansion cracks; red staining } \\
\text { of the surrounding silicates. The dark colored ba- } \\
\text { salt has larger skeletal grains that are less altered; } \\
3.4 \mu, 2.1,-\end{array}$ & $\begin{array}{l}\text { Some very small indet. grains in } \\
\text { the darker basalt }\end{array}$ & \\
\hline $\begin{array}{l}320 \mathrm{~B}-5 \text { (bit sample) } \\
\text { (2) }\end{array}$ & $\begin{array}{l}\text { Highly altered anhedral and skeletal grains, } \\
\text { showing high reflectivity and partial or nearly } \\
\text { complete replacement by filamentary develop- } \\
\text { ments of a dark gray phase; red staining of the } \\
\text { surrounding silicates; } 9.1 \mu, 1.4,-\end{array}$ & Rare rounded grains; $2.0 \mu, 0.01$ & $\begin{array}{l}\text { Small amounts of } \\
\text { euhedral ilmenite }\end{array}$ \\
\hline $321-13-4,91-94(2)$ & $\begin{array}{l}\text { Skeletal grains of variable reflectivity and, in } \\
\text { some cases, peripheral corrosion and replacement } \\
\text { by nonopaque phases; larger grains are mottled } \\
\text { and contain expansion cracks; some red staining } \\
\text { of silicates surrounding oxide grains; } 9.2 \mu, 2.3,2.1\end{array}$ & Rare small indet. grains; $4.9 \mu$, & $\begin{array}{l}\text { Iron hydroxide, } \\
2.6 \mu, 0.008\end{array}$ \\
\hline $321-13-4,142-145(2)$ & $\begin{array}{l}\text { Skeletal grains of high reflectivity; silicates stained } \\
\text { red-brown adjacent to oxides; } 12 \mu, 0.18,1.2\end{array}$ & Rare small indet. grains; $2.6 \mu, 0.02$ & Ilmenite $4.7 \mu, 0.01$ \\
\hline $321-14-1,39-42(1)$ & $\begin{array}{l}\text { Anhedral to subhedral, rarely skeletal form; } \\
\text { homogeneous grains with rare expansion cracks; } \\
\text { no other indications of alteration; } 25 \mu, 4.0,6.8\end{array}$ & Some pyrite & \\
\hline $321-14-1,39-42(2)$ & $\begin{array}{l}\text { Anhedral to subhedral grains about half of which } \\
\text { have rare expansion cracks; no other indications } \\
\text { of alteration }\end{array}$ & Some pyrite $; 4.4 \mu, 0.16$ & Ilmenite; $67 \mu, 0.01$ \\
\hline $321-14-1,58-61(2)$ & $\begin{array}{l}\text { Anhedral to subhedral form with rare expansion } \\
\text { cracks, the only indications of alteration; } 21 \mu \text {, } \\
3.8,5.2\end{array}$ & Rare small indet. grains; $3.2 \mu, 0.04$ & Ilmenite $; 5.1 \mu, 0.01$ \\
\hline $\begin{array}{l}321-14-2,12-15(1) \\
\text { and }(2)\end{array}$ & $\begin{array}{l}\text { Two size generations, large skeletal to subhedral } \\
\text { grains and a smaller generation, sometimes fringing } \\
\text { the larger grains; no indications of alteration; } 18 \mu \text {, } \\
3.5,5.5\end{array}$ & $\begin{array}{l}\text { Pyrite, sometimes rimmed with a } \\
\text { dark colored magnetite; } 3.9 \mu, 0.23\end{array}$ & \\
\hline
\end{tabular}


TABLE 1 - Continued

\begin{tabular}{|c|c|c|c|}
\hline \multirow{2}{*}{$\begin{array}{c}\text { Sample } \\
\text { (Interval in } \mathrm{cm} \text { ) }\end{array}$} & \multicolumn{2}{|c|}{ Description, Grain Size Content (\% by volume) } & \multirow[b]{2}{*}{ Other Phases } \\
\hline & Titanomagnetite $^{\mathrm{a}}$ & Sulphides & \\
\hline $321-14-2,117-120(2)$ & $\begin{array}{l}\text { Anhedral and rarely subhedral or skeletal form; } \\
\text { no indications of alteration; } 5.2 \mu, 1.9,5.3\end{array}$ & Some pyrite; $1.4 \mu, 0.01$ & $\begin{array}{l}\text { Ilmenite } ; 5.5 \mu, 0.06 \\
\text { Iron hydroxide } \\
5.7 \mu, 0.04\end{array}$ \\
\hline $321-14-3,34-37(1)$ & $\begin{array}{l}\text { Two size generations, large skeletal to subhedral } \\
\text { and less commonly a smaller generation fringing } \\
\text { the larger grains; expansion cracks rare if present } \\
\text { at all; a hint of orange-red staining of silicates the } \\
\text { only other indication of alteration }\end{array}$ & Abundant pyrite & \\
\hline $321-14-3,34-37(2)$ & $\begin{array}{l}\text { Two size generations as in wafer ( } 1 \text { ); no indica- } \\
\text { tions of alteration; } 27 \mu, 4.2,4.6 \text {. (averaged } 1 \text { and } \\
\text { 2) }\end{array}$ & $\begin{array}{l}\text { Abundant sulfides, sometimes } \\
\text { polyphase pyrite and pyrrhotite. } \\
\text { Some larger grains have dark col- } \\
\text { ored oxide halos; } 6.6 \mu, 0.22\end{array}$ & \\
\hline $321-14-3, \quad 44-47 \quad(2)$ & $\begin{array}{l}\text { Two size generations, large skeletal to subhedral } \\
\text { grains with fringes of smaller grains; no indica- } \\
\text { tions of alteration; } 25 \mu, 3.7,6.2\end{array}$ & $\begin{array}{l}\text { Abundant sulfides, some with } \\
\text { probably chalcopyrite exsolution, } \\
\text { others with dark colored oxide } \\
\text { halos; } 7.4 \mu, 0.22\end{array}$ & \\
\hline $321-14-4,20-23(2)$ & $\begin{array}{l}\text { Skeletal to anhedral forms; no indications of al- } \\
\text { teration; } 22 \mu, 3.9,17.8\end{array}$ & $\begin{array}{l}\text { Pyrite dominant, some sulfides } \\
\text { with probable chalcopyrite exsolu- } \\
\text { tion, others with dark colored } \\
\text { halos; } 7.7 \mu, 0.18\end{array}$ & \\
\hline $321-14-4,45-48(2)$ & $\begin{array}{l}\text { Skeletal to subhedral forms; no indications of al- } \\
\text { teration; } 29 \mu, 4.9,5.1\end{array}$ & $\begin{array}{l}\text { Abundant sulfides, some with } \\
\text { probable chalcopyrite exsolution, } \\
\text { others with dark colored oxide } \\
\text { halos; } 8.9 \mu, 0.34\end{array}$ & \\
\hline $157-49-1,136-138$ & $\begin{array}{l}\text { Two size generations; large skeletal to anhedral } \\
\text { grains with fringes of the smaller generation; pe- } \\
\text { ripheral slight alteration and granulation and } \\
\text { some expansion cracks }\end{array}$ & Large grains of probable pyrite & \\
\hline $157-49.2,1-3$ & $\begin{array}{l}\text { Skeletal to anhedral form; expansion cracks with } \\
\text { associated peripheral granulation }\end{array}$ & Small grains & \\
\hline$\cdot 157-49-2,64-66$ & $\begin{array}{l}\text { Skeletal to anhedral form; expansion cracks with } \\
\text { associated slight granulation; some reddening of } \\
\text { surrounding silicates }\end{array}$ & $\begin{array}{l}\text { Abundant small grains, possibly } \\
\text { of pyrrhotite }\end{array}$ & \\
\hline $157-49-2,135-137$ & $\begin{array}{l}\text { Skeletal to anhedral grains with abundant exsolu- } \\
\text { tion lamellae deuteric class } 2 \text {; little granulation }\end{array}$ & Abundant sulfide & \\
\hline
\end{tabular}

${ }^{a}$ Magnetite volume values are from optical and saturation magnetic measurements, respectively.

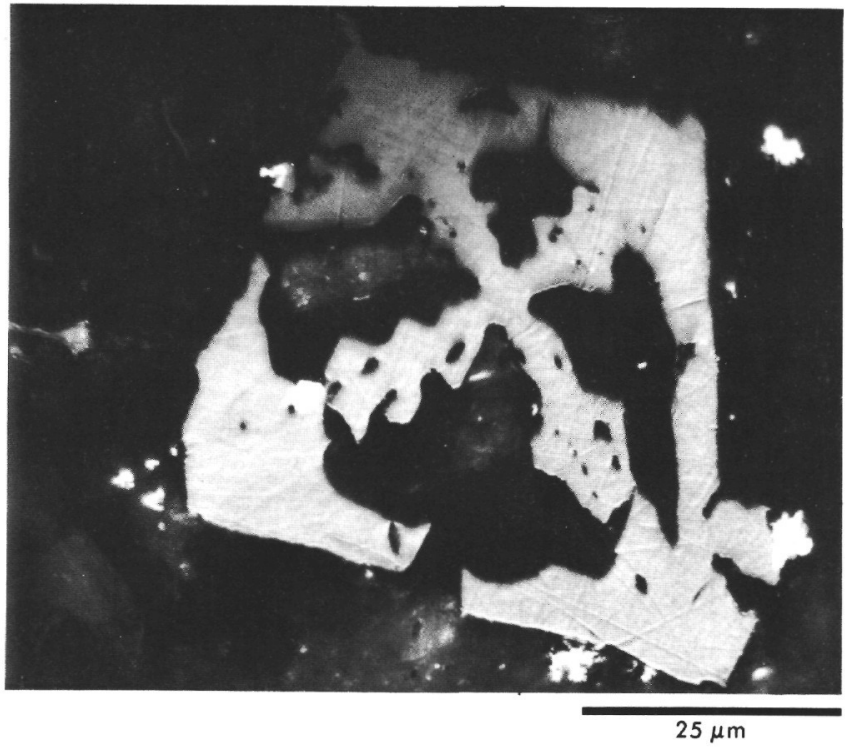

Figure 1. Skeletal titanomagnetite (gray) and sulfide (white) (321-14-2, 12-15 cm). massive basalts two size generations of magnetite are present-the larger of up to $100 \mu$ size and usually anhedral to subhedral in form and the smaller of skeletal form and from $10 \mu$ down to the limit of visibility at about $1 / 4 \mu$. At less than $1 \mu$, opaque grains are detected by their diffraction patterns, and as a consequence of this, internal features cannot be distinguished. In these samples the smaller size generation often occurs both in the ground mass and as fringes around the perimeters of large grains (Figure 4). Several explanations can be envisioned for the two size generations. The larger size generation may have formed before eruption, or in ponded lavas. In pillows, the smaller size generation is likely to have formed as a result of rapid conductive cooling. In the massive lavas the origin of the smaller size generation may lie in the catastrophic final solidification of ponded lavas on seawater entering tensional joints that formed during the last stages of crystallization.

At high magnification, stoichiometric high titanium titanomagnetite, viewed with an oil-immersion objective, is a homogeneous medium brown color. Grains with this type of appearance are found exclusively in a 


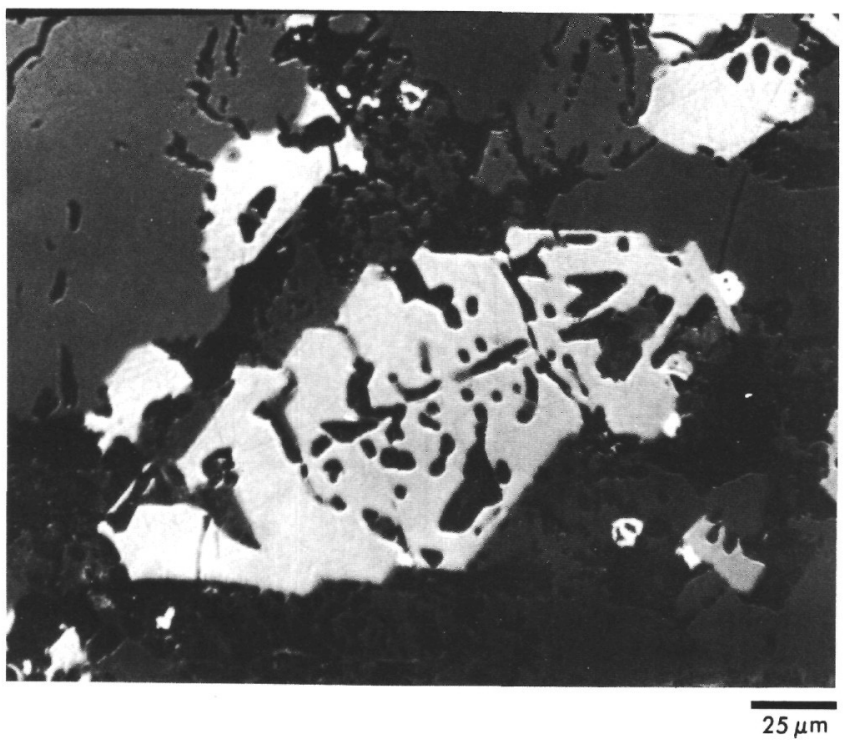

Figure 2. Skeletal to subhedral titanomagnetite (gray) and sulfide (white) (321-14-4, 20-23 cm).

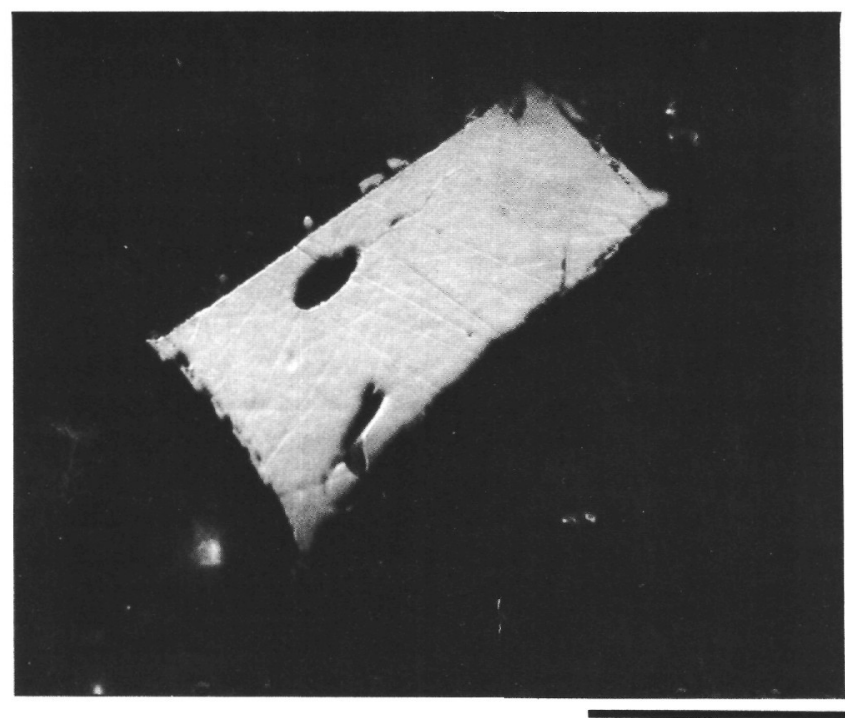

$25 \mu \mathrm{m}$

Figure 3. Subhedral titanomagnetite with a partial fringe of titanomagnetite of a smaller sized generation (321-14-3, 44-47 cm [2]).

small number of massive basalt samples from Sites 319 and 321 (Table 1, Figures 1,2,3, and 13). Elsewhere, they occur rarely if at all, indicating that various types of alteration have affected the presumably original stoichiometric titanomagnetite.

During the postcrystallization history of a basalt lava, alteration of the titanomagnetite can first take place during initial cooling between $500^{\circ} \mathrm{C}$ and $800^{\circ} \mathrm{C}$ (Sato and Wright, 1966; Lindsley, 1962, 1965). This type of alteration has been termed deuteric or high temperature oxidation. In subaerial lavas its development is typically patchy, but tends to favor the interiors of flows. Grommé et al. (1969) found that the quenched upper surfaces of ponded Hawaiian lavas do not show deuteric oxidation, presumably as a result of the short time

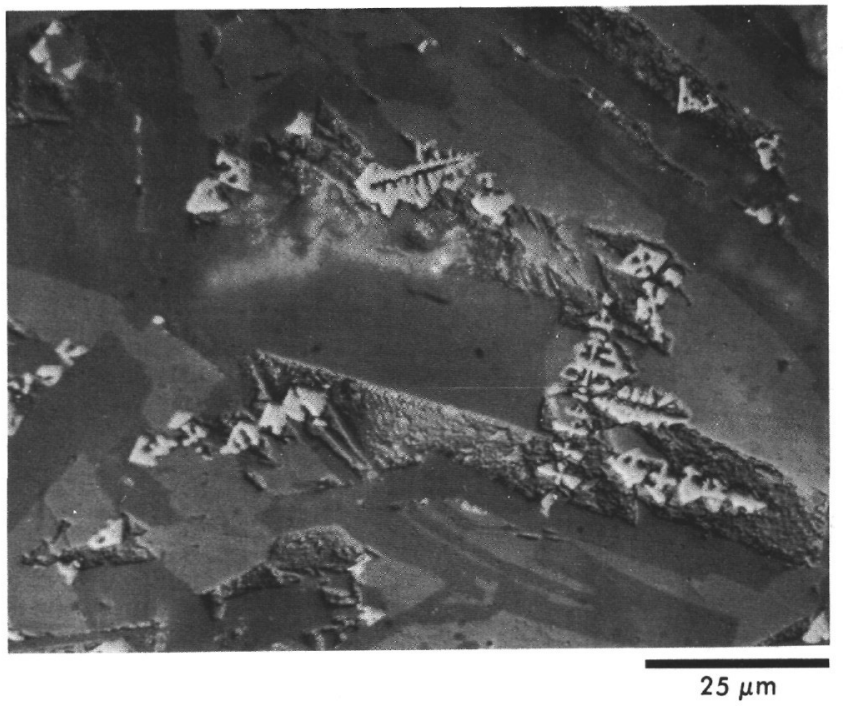

Figure 4. Skeletal titanomagnetite in fine-grained basalt (319A-7-1, 40-43 cm [1]).

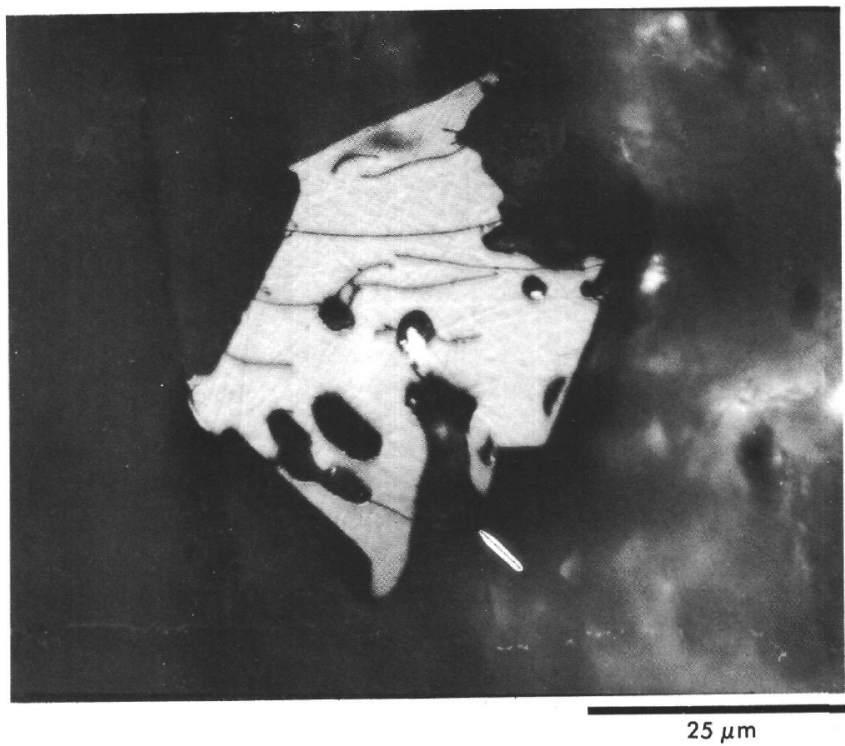

Figure 5. Limited development of volume change cracks in a medium brown skeletal to anhedral titanomagnetite (321-14-2, $39-42 \mathrm{~cm}$ [2]).

available for reaction even if oxidizing conditions prevail. The absence of deuteric oxidation from oceanic pillow lavas is consistent with their quench history. With the limited number of samples of coarse-grained basalts from the interior of submarine lava flows previously available, it has been uncertain whether deuteric oxidation is as widespread in the deep ocean as in the subaerial environment. Only three previous records of deuteric oxidation of titanomagnetite in ocean floor rocks are known to us. Basaltic hyaloclastite sandstones recovered at DSDP Site 115 contain large magnetites showing most of the stages of deuteric oxidation (ilmenite exsolution and further oxidation to rutile, pseudobrookite, and titanohematite, that is, constituting oxidation classes 1,2,4,5, and 6 of Ade-Hall et al., 1968, Ryall in Laughton et al., 1972). However, 


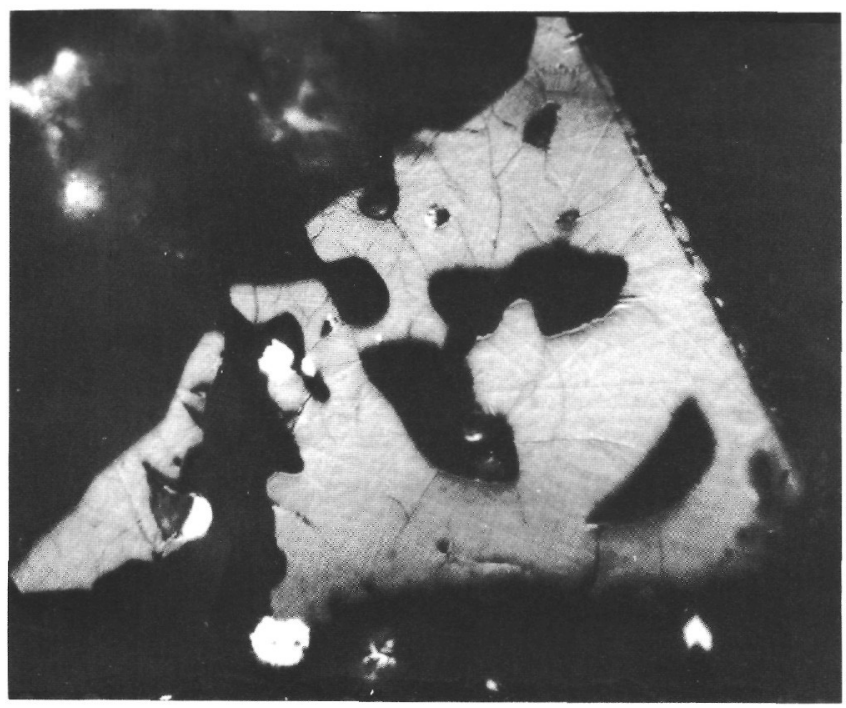

Figure 6. Limited development of volume change cracks in a medium brown skeletal to anhedral titanomagnetite. Note partial fringe of finer grain sized titanomagnetite (319A-3-2, 108-111 cm [2]).

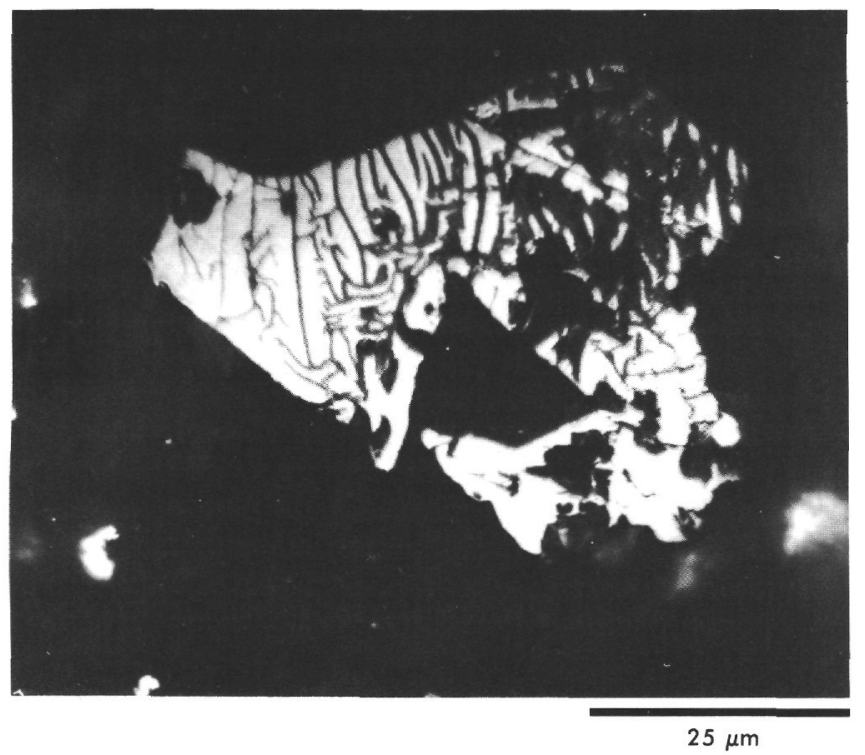

Figure 7. Extensive development of volume change cracks, general lightening in color and increase in reflectivity, and partial replacement of titanomagnetite by a dull gray phase (upper right) (321-13-4, 91-94 cm [2]).

Walker (in Laughton et al., 1972) considers that the hyaloclastic material was derived from Iceland and, as such, may be the product of subaerial volcanism. Deuteric oxidation in definitely submarine material was found in 8 of 25 samples in a collection of basalt samples from several DSDP Leg 26 sites (Ade-Hall, 1974). The maximum state of alteration, where ilmenite exsolution lamellae are themselves oxidized, corresponds to class 4 on the six class scale. Finally, Irving et al. (1970) report that 9 of 34 samples dredged from the Mid-Atlantic

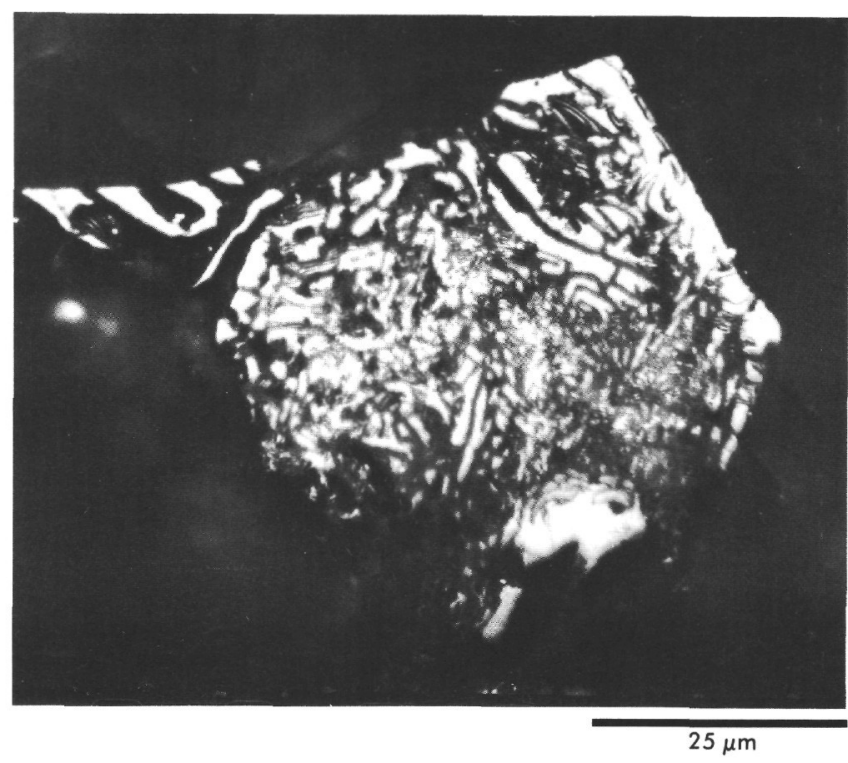

Figure 8. Extensive development of volume change cracks, general lightening in color and increase in reflectivity, and replacement of titanomagnetite by a dull gray phase (319A-3-2, 108-111 cm [2]).

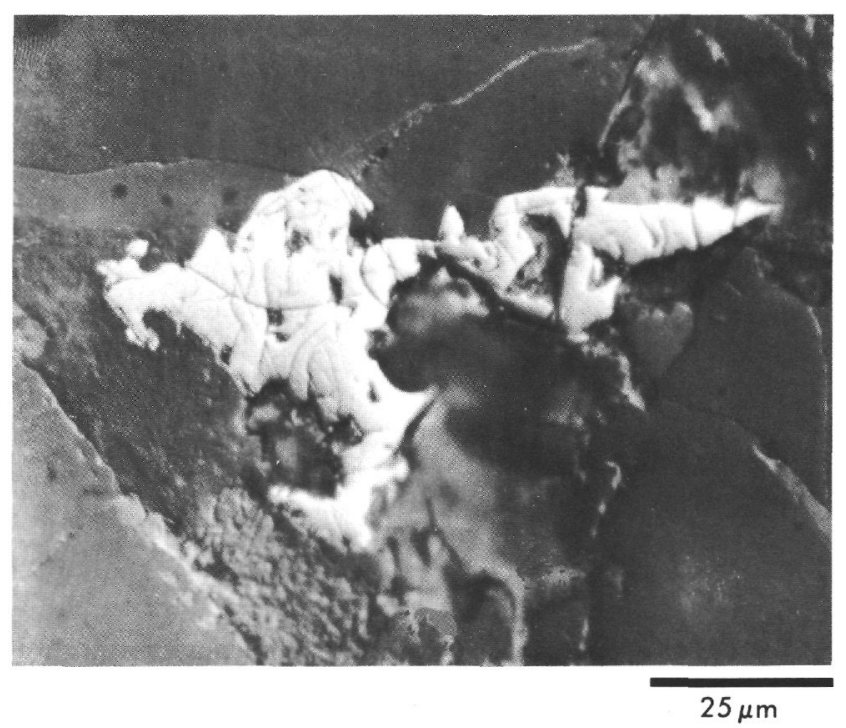

Figure 9. Incipient development of volume change crack texture in skeletal grain of titanomagnetite lightened in color to pale bluish-gray. No replacement by secondary gray phase in cracks (319A-3-2, 108-111 cm [1]).

Ridge crest near $45^{\circ} \mathrm{N}$ contained magnetites of classes 2 or 3 . In contrast, 20 samples from DSDP Legs 2 to 6 were quite free from deuteric oxidation (Kitazawa and Ade-Hall, 1972), this being a typical result for collections consisting of pillow fragments. Three of the coarser grained Nazca plate basalts (319A-2-1, 140-143 $\mathrm{cm}$; 3-2, 108-111 cm [2]; and 157-49-2, 135-137 cm) clearly have experienced mild deuteric oxidation (classes 2 and 3), as is indicated by the presence of ilmenite lamellae (Figures 18 and 19). In the case of the Site 319 basalts, at least, the coarse-grained basalts form parts of 


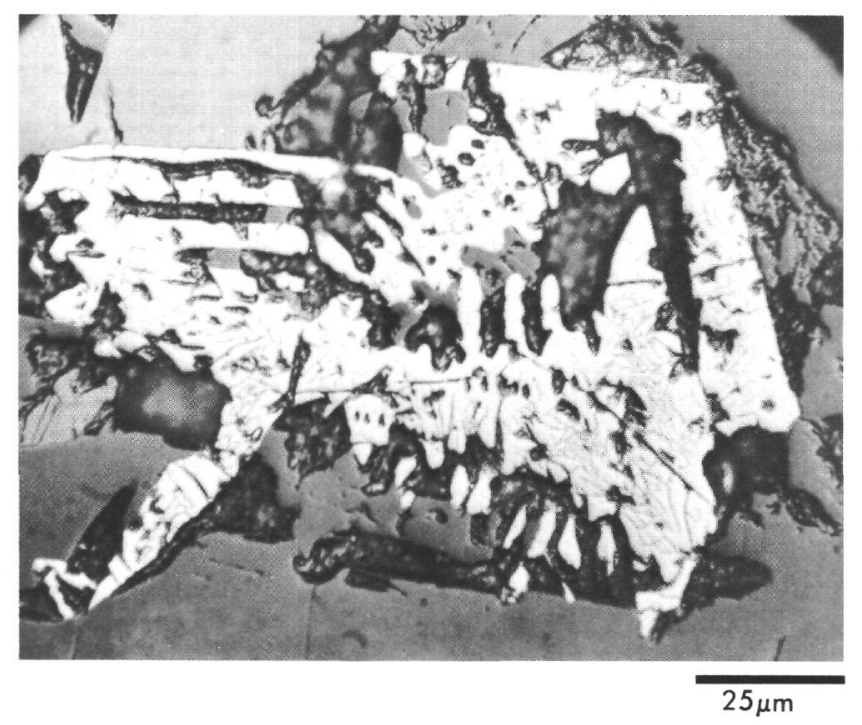

Figure 10. Incipient replacement of skeletal titanomagnetite in extensively developed volume change cracks by secondary gray phase. Crystal form is typical of quench texture marine basalts. General lightening of titanomagnetite color and increase in reflectivity (319A-3-2, 108$111 \mathrm{~cm} \mathrm{[1]).}$

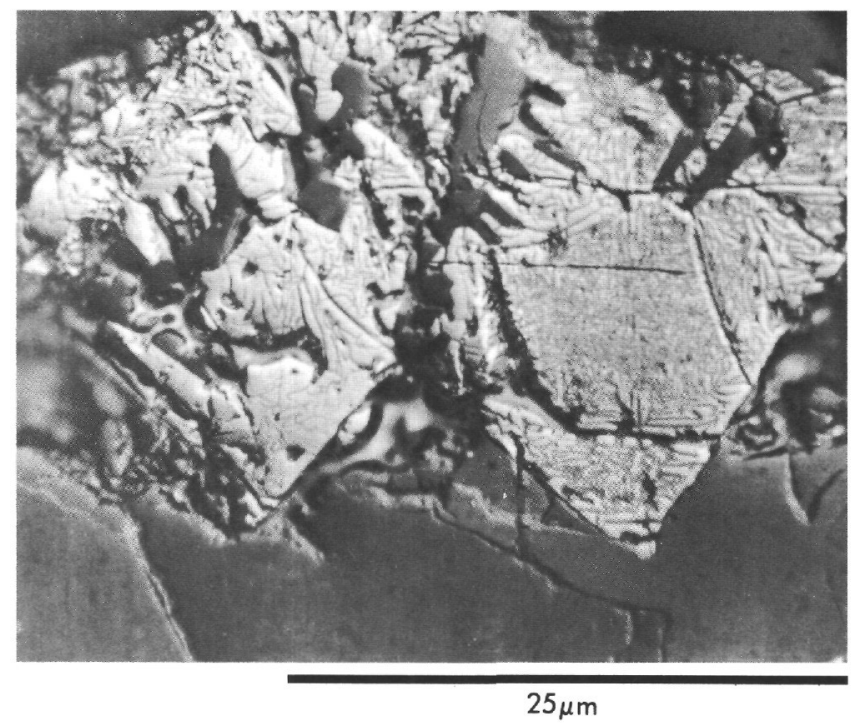

Figure 11. Unequal development of volume change crack textures in skeletal to subhedral titanomagnetite. Greater degree of replacement by secondary gray phase in righthand grain has proceeded to greatest extent in center of grain and is accompanied by golden yellow internal reflections (not visible in photograph) $(319 A-3-2,108-111 \mathrm{~cm}$ [1]).

a sequence of massive basalts, perhaps representing the interior of a flow. This is a typical environment of occurrence for deuteric oxidation in subaerial basalts.

In Sample 319A-2-1,140-143 cm deuteric oxidation increases sharply towards a vein-filled crack. This suggests that at least some of the cracks in the massive basalts, now infilled with veins of low temperature phases such as smectite, originated during initial cooling.

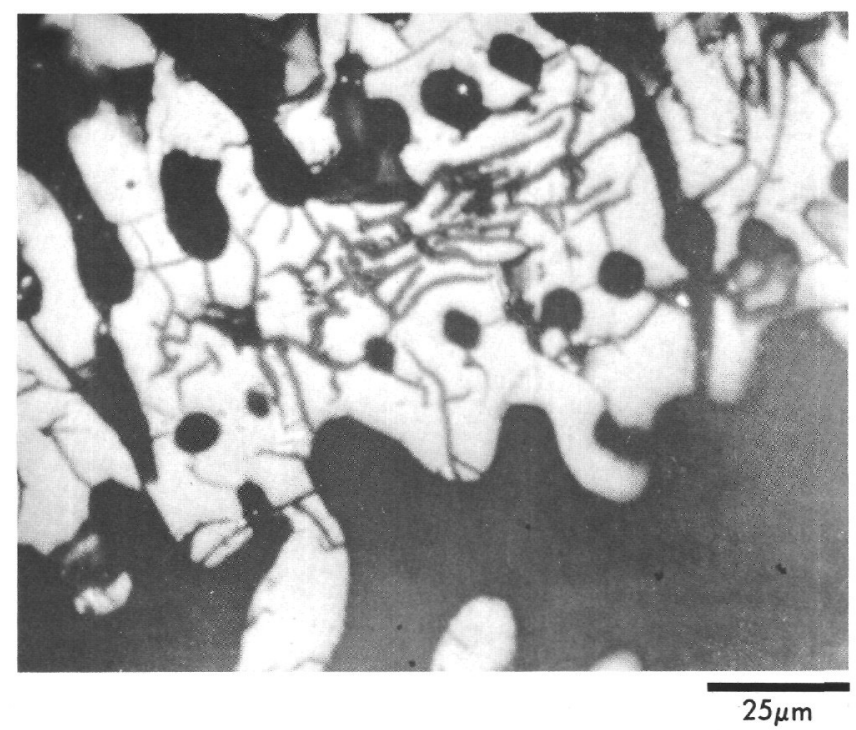

Figure 12. Enlargement of lightened skeletal titanomagnetite showing extensive replacement of titanomagnetite in volume change cracks by secondary gray phase (319A-3-2, $108-111 \mathrm{~cm} \mathrm{[1]).}$

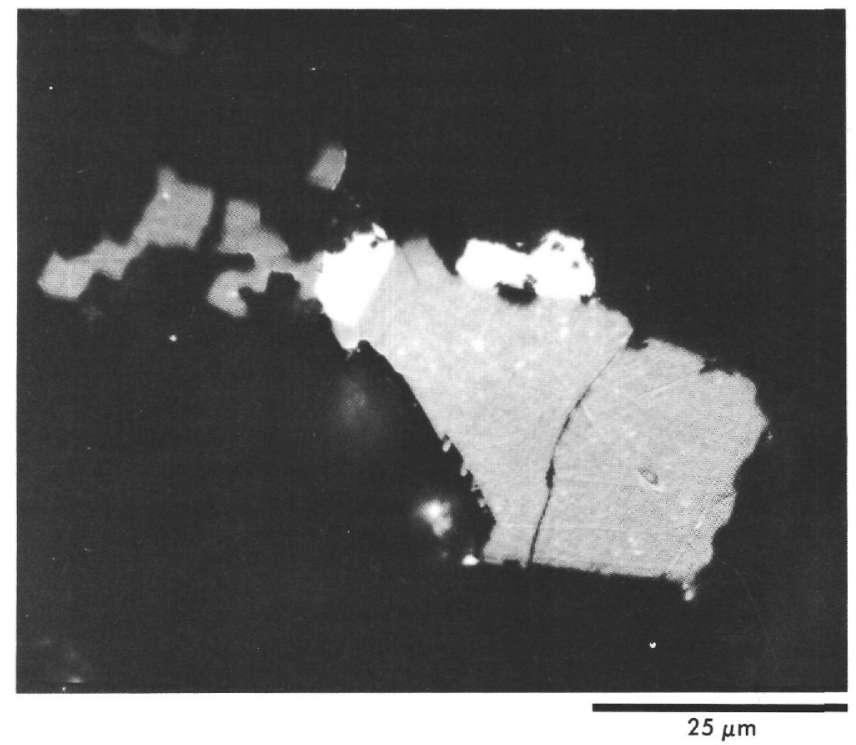

Figure 13. Euhedral pyrite (white) in association with subhedral titanomagnetite (gray) (321-14-2, $117-120 \mathrm{~cm})$.

The very limited degree of development of deuteric oxidation, even in the more massive Nazca plate basalts, suggests that the deep ocean environment is less favorable for the occurrence of this type of alteration than is the subaerial environment. This result is consistent with a suggestion by Sato and Wright (1966) that hydrogen from dissociated water vapor must be lost from a flow for deuteric oxidation to be able to proceed. The high confining pressure of the deep ocean environment must considerably reduce gas loss from a cooling flow. The deep ocean environment is in this respect more like the intrusive environment. Deuteric oxidation 

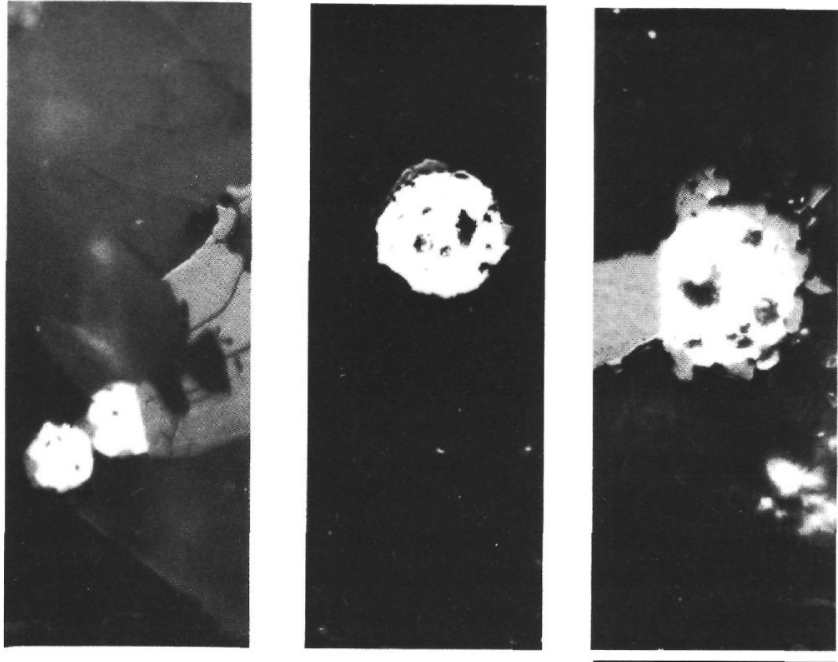

$25 \mu \mathrm{m}$

Figure 14. Rounded pyrite or pyrite-pyrrhotite grains partially rimmed with magnetite (321-14-1, 39-42 cm [2]): (319A-4-1, 133-136 cm [2]); and (321-14-4, 20-23 cm [2]).

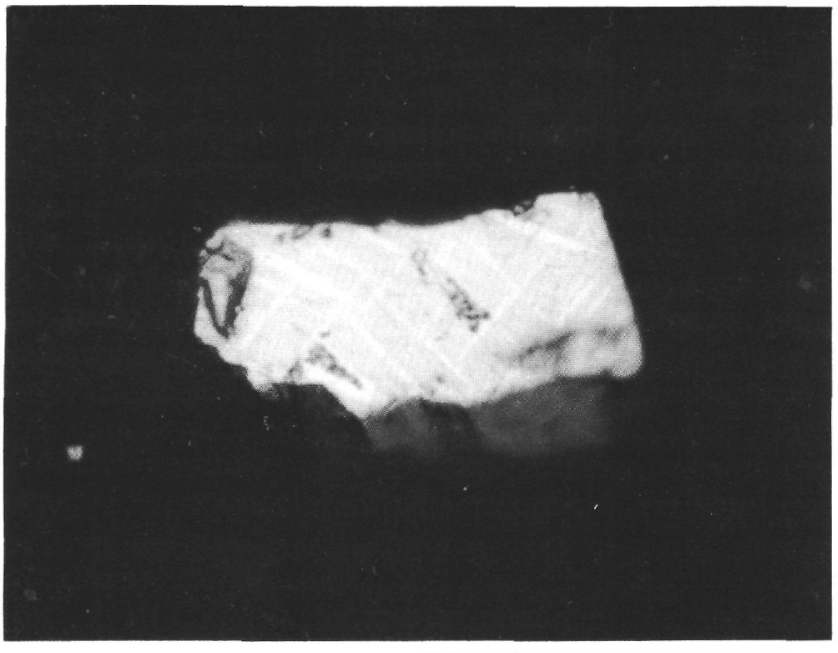

$25 \mu \mathrm{m}$

Figure 15. Chalcopyrite lamellae in a pyrrhotite base (319A$3-5,81-84 \mathrm{~cm} \mathrm{[2]).}$

is typically subdued in basaltic intrusives, where gas loss during cooling must also be relatively restricted. Other facts supporting the restricted outgassing of submarine extrusives are the presence of sulfides (characteristic of basaltic intrusives but almost completely absent from subaerial extrusives) and of excess argon (Dalrymple and Moore, 1968).

In addition to the rare occurrence of ilmenite exsolution lamellae, a range of other postinitial crystallization changes are seen in the titanomagnetites. The most common is color change. Titanomagnetites from which alteration features are entirely lacking are homogeneous with medium brown color. A mottling in this medium brown of lighter browns or off-white is evident in many

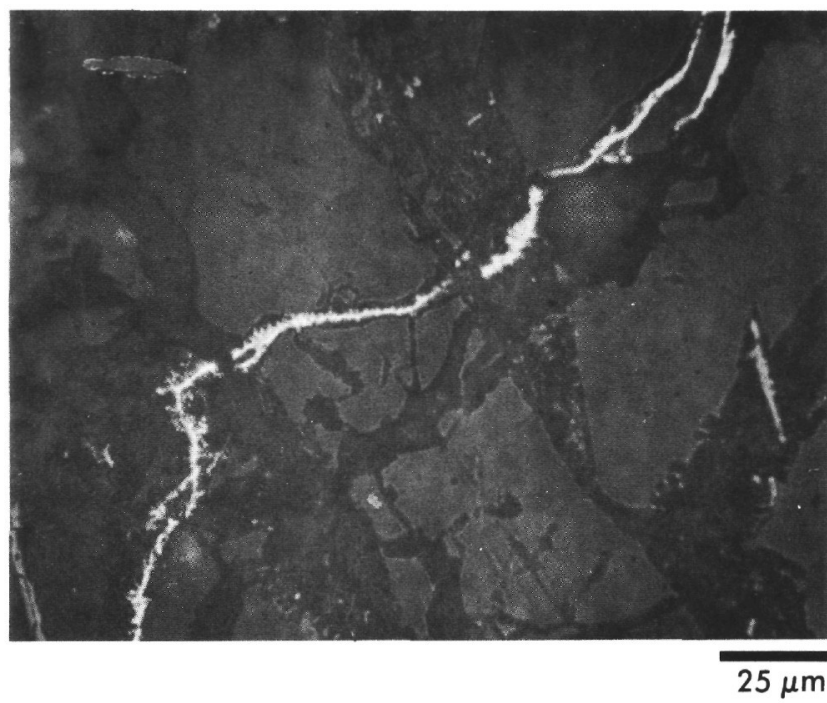

Figure 16. Secondary pyrite vein (319A 2-1, 140-143 cm).

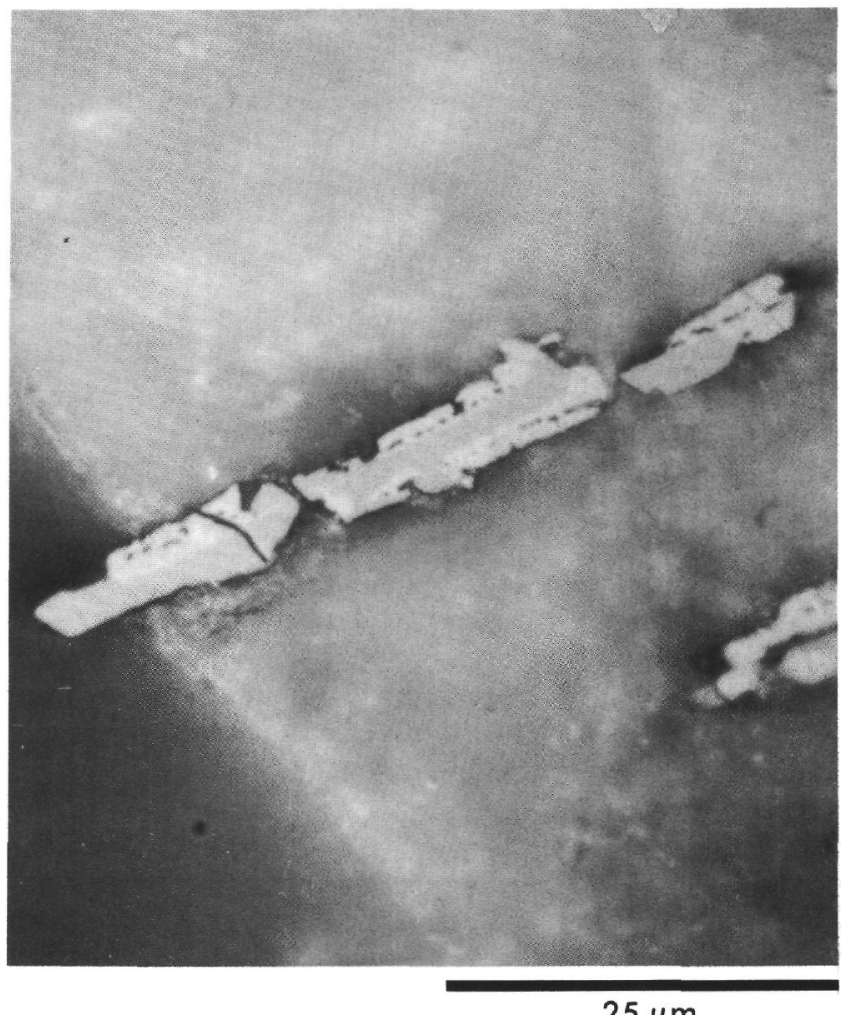

$25 \mu \mathrm{m}$

Figure 17. Ilmenite lath mantled by two size generations of cation-deficient titanomagnetite (319A-2-1, 106-109 cm [1]).

grains and is associated with other alteration features, such as the development of patterns of curved and branching cracks (Figures 5 to 12). The presence of these cracks is taken as implying that volume change, associated with low temperature oxidation, has taken place. Other magnetites show very extensive or complete lightening in color, until all grains are off-white or very pale purple-brown. Magnetites with these colors are often surrounded by red-stained silicates, suggesting 


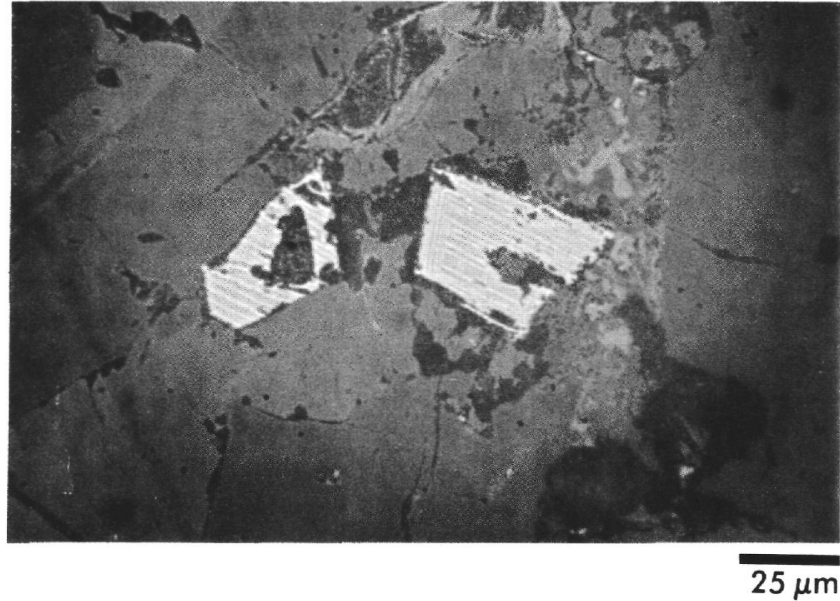

Figure 18. Anhedral titanomagnetite now psuedomorphed by low titanium magnetite (gray) with abundant ilmenite lamellae (off-white). Deuteric oxidation class 3 (319A-2$1,140-143 \mathrm{~cm})$.

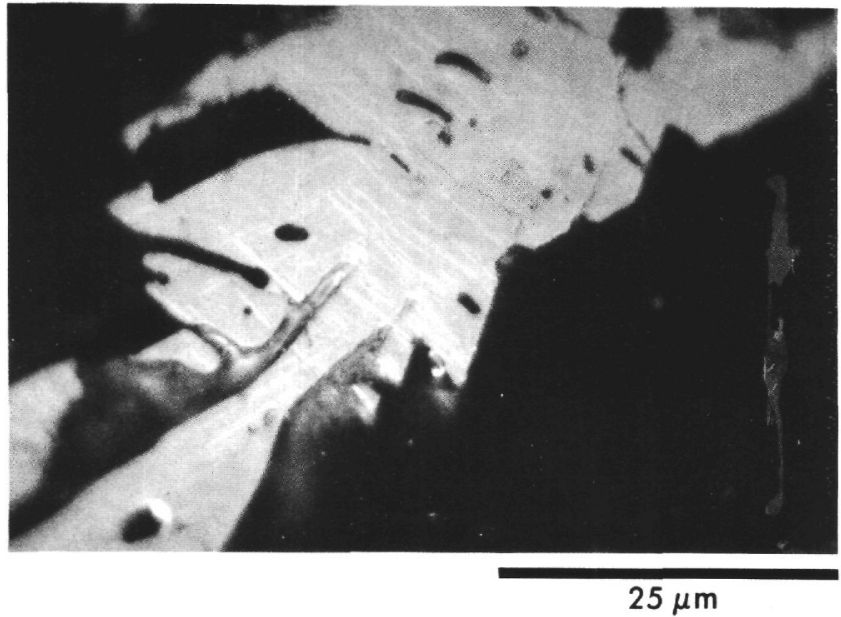

Figure 19. Skeletal to subhedral titanomagnetite with some ilmenite lamellae. Deuteric oxidation class 2 (157-49-2, $135-137 \mathrm{~cm}$ ).

that some iron has been expelled from the magnetite during oxidation. More altered magnetites in the massive basalts show replacement of the cubic phase adjacent to volume change cracks by a dull gray, finely divided phase (Figures 7 to 12). In the most altered grains a large part of the magnetite is replaced by this gray phase (Figures 8 and 11) and yellow flecks of another secondary phase.

All of these features are seen in subaerial basalts. The progressive cracking and color change are found in the titanomagnetites of subaerial lavas which have only experienced low temperature alteration near ambient temperatures, probably as the result of weathering, before the onset of zeolite facies metamorphism (AdeHall et al., 1971). In the deep ocean environment the comparable process is halmyrolysis, a term used to describe the extensive chemical exchange between lava and seawater close to $0^{\circ} \mathrm{C}$ (Hart, 1973). We suggest that this suite of titanomagnetite alteration features are the

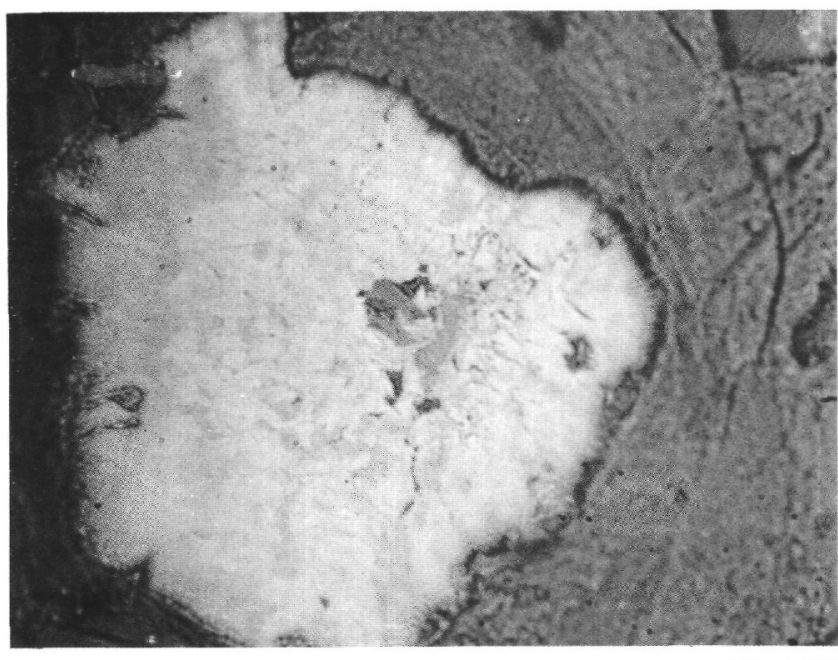

$25 \mu \mathrm{m}$

Figure 20. Botryoidal development of secondary hematite or iron hydroxide lining the wall of a vein (319A-2-1, $140-143 \mathrm{~cm}$ ).

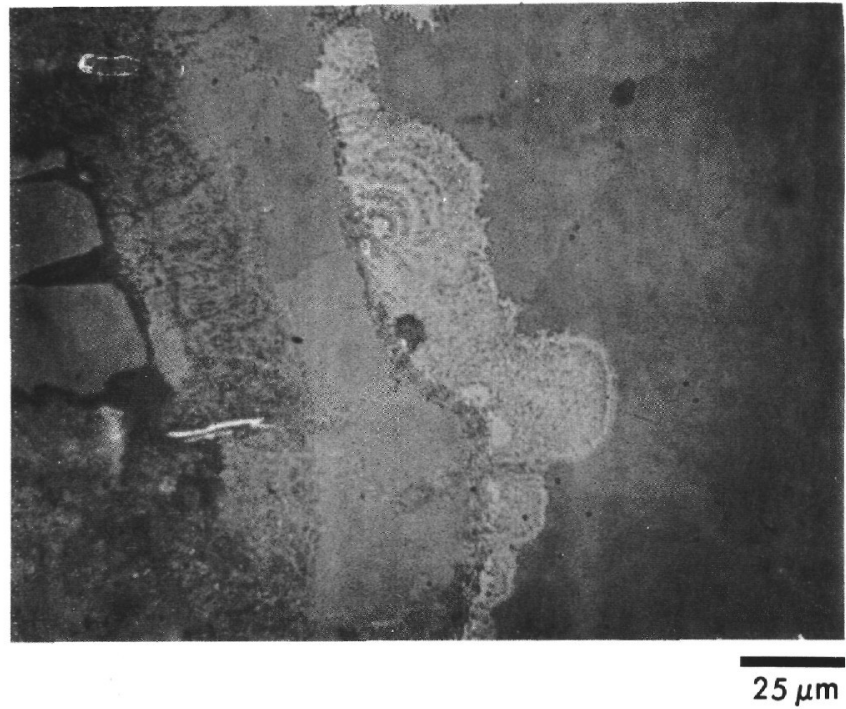

Figure 21. Polycrystalline mass of secondary hematite or iron hydroxide at the center of an area of red-stained silicate minerals (319A-1-1, 39-42 cm [2]).

products of low temperature oxidation taking place during the halmyrolysis of the Nazca plate basalts. A number of other titanomagnetite alteration products, such as patches of rutile or anatase granules, occur commonly in zeolite facies subaerial lavas. These require $150^{\circ} \mathrm{C}$ or more for their formation. Their absence from the Nazca plate basalts is consistent with the shallow depths of the samples in the basement sequences and testifies to the absence of hydrothermal (zeolite facies) metamorphic conditions in the past within the basement sequences at these sites.

Titanomagnetite content and average grain size range from $0.18 \%$ to $4.9 \%$ by volume and from $1.6 \mu$ to $29 \mu$. These parameters are strongly correlated, with low con- 
tents and small grain sizes characterizing pillow fragments and high contents and large grain sizes characterizing the coarse-grained massive basalt samples. The correlation of titanomagnetite and basalt grain size was anticipated from the results of other studies. Presumably, increase in titanomagnetite content with basalt grain size is explained by the more complete crystallization of the massive, slowly cooled material.

\section{Ilmenite}

Ilmenite is an uncommon opaque phase in the Nazca plate basalts. It has been detected only in the coarser grained basalts, where at the most it amounts to $40 \%$ by volume of the titanomagnetite, although usually amounting to $10 \%$ or less. The ilmenite occurs in two forms, as discrete usually subhedral to euhedral grains crystallized as a primary phase sometimes mantled by titanomagnetite (Figure 17) and as subsolidus exsolution lamellae in titanomagnetite (Figures 18 and 19).

\section{Other Iron Oxides and Hydroxides}

These occur occasionally and are strongly associated with altered areas and veins in the coarser grained Site 319 basalts (Figures 20 and 21).

\section{Sulfides}

The sulfides are a widespread but never dominant group of minerals in the Nazca plate basalts. Different phases occur with one being found in clearly distinguishable primary and secondary generations.

Pyrite is the commonest sulfide. It occurs in several forms: as subhedral to euhedral primary grains (Figure 13); as primary spherules, suggesting liquid immiscibility, sometimes rimmed with a halo of a dull gray cubic phase (Figure 14); and in veins (Figure 16).

The spherules of pyrite rimmed with dull gray cubic phase frequently contain pyrrhotite irregularly intergrown with the pyrite. The rim grains invariably have good crystal form suggesting high temperature formation. Microprobe analysis of a rim grain in Samples $319 \mathrm{~A}-3-5,81-84 \mathrm{~cm}(2)$ indicates that it is an iron oxide with less than $1 \% \mathrm{TiO}_{2}$. This low titanium content clearly distinguishes this phase from the typical titanomagnetites of the rock, which contain approximately $21 \% \mathrm{TiO}_{2}$. This compositional difference suggests different origins for the two magnetite habits. One explanation for the oxide-sulfide relationship which fits the observations is that it represents the incomplete high temperature oxidation of pyrrhotite to pyrite. Complete oxidation would be described by:

$$
8 \mathrm{Fe}_{0875} \mathrm{~S}+2 \mathrm{O}_{2} \rightarrow 4 \mathrm{FeS}_{2}+\mathrm{Fe}_{3} \mathrm{O}_{4}
$$

i.e., pyrrhotite + oxygen $\rightarrow$ pyrite + magnetite.

Measurements of the relative volumes of sulfides and oxides for the grains illustrated in Figure 14 indicate that, on the average, only $0.60 \pm 0.05$ (standard deviation of the mean) molecules of magnetite are present. This would be consistent with incomplete oxidation, as is the frequent presence of unoxidized pyrrhotite in the sulfide cores of the composite grains. The veins of pyrite are clearly of secondary origin and are associated with fractures in the coarse-grained basalts at Site 319. Since these fractures acted as foci of both deuteric and low temperature alteration, it is not possible to identify the conditions in which the pyrite veining occurred.

The anisotropic sulfide, pyrrhotite, occurs widely, sometimes as discrete grains and in other instances, as mentioned above, in composite grains with pyrite.

Very occasionally, in most of the coarse-grained Site 319 basalts, composite sulfide grains are found such as is shown in Figure 15. These grains consist of exsolution lamellae of chalcopyrite in a pyrrhotite base.

\section{Progressive Cation Deficiency in Titanomagnetites}

A number of low temperature halmyrolytic alteration features of titanomagnetite are described (Figures 5 to 12). A comparison of magnetic properties and these alteration features allows the latter to be interpreted in terms of an increasing degree of cation deficiency of titanomagnetite (Table 2).

Clearly the petrological features listed earlier mostly indicate high degrees of cation deficiency. That is, general increase in reflectivity, red staining of surrounding silicates, and replacement of magnetite by a dull gray phase have corresponding overlapping ranges of cation deficiency of from 0.67 to 0.91 . (Cation deficiency here is defined as the fraction of $\mathrm{Fe}^{2+}$ replaced by $\mathrm{Fe}^{3+}$ in the titanomagnetite molecule.) It is not surprising to find that highly cation-deficient phases are the most easily detected by optical examination. However, the problem remains of the optical distinction between titanomagnetites of various but low degrees of cation deficiency. Table 2 shows that volume change cracks and color mottling are possible indicators in the range $0.0 \leq z \leq 0.67$. Further work will include measurement of the degree of volume change crack development and of color change. Judgment of the latter feature is notoriously subjective and it will require the use of a microspectrophotometer to obtain objective results.

\section{Variation of Titanomagnetite Alteration State in the Vicinity of a Vein in \\ Massive Basalt from Site 319}

The massive basalts at Site 319 are characterized by vein-filled fractures that clearly have acted as the foci of deuteric and perhaps later alteration (Bass, this volume). Sample 319A-2-1,140-143 cm was taken to examine the change in titanomagnetite in the vicinity of such a fracture. This minicore was drilled through the main core approximately normal to a fracture. The minicore was then split and one-half polished for work with the ore microscope. Figure 22 shows the macroscopic appearence of the polished surface.

Examination of the titanomagnetite along a profile normal to the vein shows continuous variation in alteration state from uniform brown grains with volume change cracks in the least altered light gray basalt to gray grains in a red-stained silicate matrix in the greenbrown altered basalt (Table 3 ). Within a millimeter of the vein, deuterically oxidized grains with exsolved ilmenite lamellae predominate. A set of seven samples, taken along the profile, was subjected to Curie point measurement, and the state of the cation deficiency of the titanomagnetite of each sample was estimated (AdeHall et al., Rock Magnetism of Basalts, this volume). Cation deficiency increases fairly regularly from 0.4 to 0.5 in the light gray basalt to a maximum of 0.96 within 
TABLE 2

Mineralogical Changes Arising From Increased Cation Deficiency in Site 319 and 321 Titanomagnetites

\begin{tabular}{|c|c|}
\hline $\begin{array}{l}\text { Degree of Cation Deficienty, } z^{\mathrm{a}} \\
\text { (Range, average [number of values]) }\end{array}$ & Mineralogical State \\
\hline $0.00-0.18,0.08[9]$ & $\begin{array}{l}\text { Uniform medium brown titanomag- } \\
\text { netite grains, no alteration features }\end{array}$ \\
\hline $0.00-0.43,0.15[8]$ & $\begin{array}{l}\text { Volume change cracks in otherwise } \\
\text { uniform colored grains }\end{array}$ \\
\hline $0.42[1]$ & Cracking and color mottling \\
\hline $0.67-0.80,0.75[5]$ & $\begin{array}{l}\text { General increase in reflectivity, sug- } \\
\text { gestive of red staining of surround- } \\
\text { ing silicates }\end{array}$ \\
\hline $0.78-0.85,0.82[3]$ & $\begin{array}{l}\text { General increase in reflectivity, } \\
\text { widespread red staining of sur- } \\
\text { rounding silicates }\end{array}$ \\
\hline $0.67-0.91,0.76[4]$ & $\begin{array}{l}\text { General increase in reflectivity, } \\
\text { widespread red staining of sur- } \\
\text { rounding silicates, and partial re- } \\
\text { placement of magnetite by a dull } \\
\text { gray phase }\end{array}$ \\
\hline
\end{tabular}

$1 \mathrm{~mm}$ of the vein (Table 3, Figure 23). The association of highly cation-deficient grains with exsolved grains appears to require two stages of alteration. The first, high temperature, initial cooling stage, produced the exsolved magnetites. These have the typical welldeveloped lamellae found where oxidation has proceeded at above $500^{\circ} \mathrm{C}$. At these high temperatures titanomagnetite can become cation deficient to only a very small extent before phase splitting occurs (Hauptman, 1974). The presence of cation deficiency, $z$, of up to 0.96 indicates that extensive very low temperature oxidation has also taken place. Ryall (in preparation) finds that at $150^{\circ} \mathrm{C}$ phase splitting takes place in cation-deficient titanomagnetite when $z$ reaches 0.6 , while Johnson and Merrill (1973) find that temperatures of $135^{\circ} \mathrm{C}$ or less are required for a phase with $z=0.55$ to be stable. Again, Seyfried et al. (this volume) find that the isotopic constitution of Site 321 secondary calcite indicates formation at $7^{\circ} \mathrm{C}$, while the absence of anhydrite as a secondary phase is consistent with the result for calcite in that halmyrolytic alteration must have taken place at $60^{\circ} \mathrm{C}$ or less. It seems that alteration and subsequent maintenance of essentially sea-floor temperatures is necessary to preserve these highly cation-deficient phases.

\section{Spatial Variation of Primary Sulfide Abundance}

The presence of sulfide veins of obvious secondary origin in zones of altered basalt (Table 1) raises the question of whether there was sufficient primary sulfide material in the flow to supply the vein material. The method used to answer this question was to measure primary and secondary sulfide contents along an interval across a polished surface, identifying all sulfide grains met along the track as primary or secondary, and measuring the size of each grain. The results are ex- pressed in Table 4 in terms of percentage of total area examined on each polished surface.

Two facts are notable, the two orders of magnitude range in primary sulfide concentration and the equivalent of the highest concentrations of primary and secondary sulfides. Concentration of primary grains could be explained by gravitational separation of the dense sulfides. Early crystallization of sulfides is a requisite for this explanation to be correct. This is appropriate as an explanation for the high sulfide content of Sample 319A-3-4,81-84 $\mathrm{cm}(2)$, which is located near the base of a flow. The other two high sulfide samples may come from the interiors of flows, possibly requiring a different explanation. However, recovery in Cores 4 and 5 of Hole 319A was very limited, and the location of the samples with respect to flow boundaries is only poorly known. The equivalence of the range of concentrations and highest values of primary and secondary sulfides allows the possibility that during a period of alteration, the former may have provided material for the latter.

\section{SUMMARY AND DISCUSSION}

The fine-grained pillow basalts recovered from the Nazca plate oceanic basement are characterized by finegrained skeletal titanomagnetite and occasional tiny sulfides, as are other oceanic pillow basalts. In contrast, the coarser grained basalts, with many titanomagnetites in the $10-100 \mu$ size range, show a greater variety of opaque phases and their alteration products. Titanomagnetite is the dominant opaque phase everywhere, with ilmenite and sulfides much less abundnat. At Sites 319 and 321 at least the composition of the stoichiometric titanomagnetite formed during initial crystallization is very close to $0.4 \mathrm{Fe}_{3} \mathrm{O}_{4} 0.6 \mathrm{Fe}_{2} \mathrm{TiO}_{4}$. In the coarse-grained basalts the magnetite shows forms transitional between skeletal, anhedral, and subhedral, and commonly occurs 

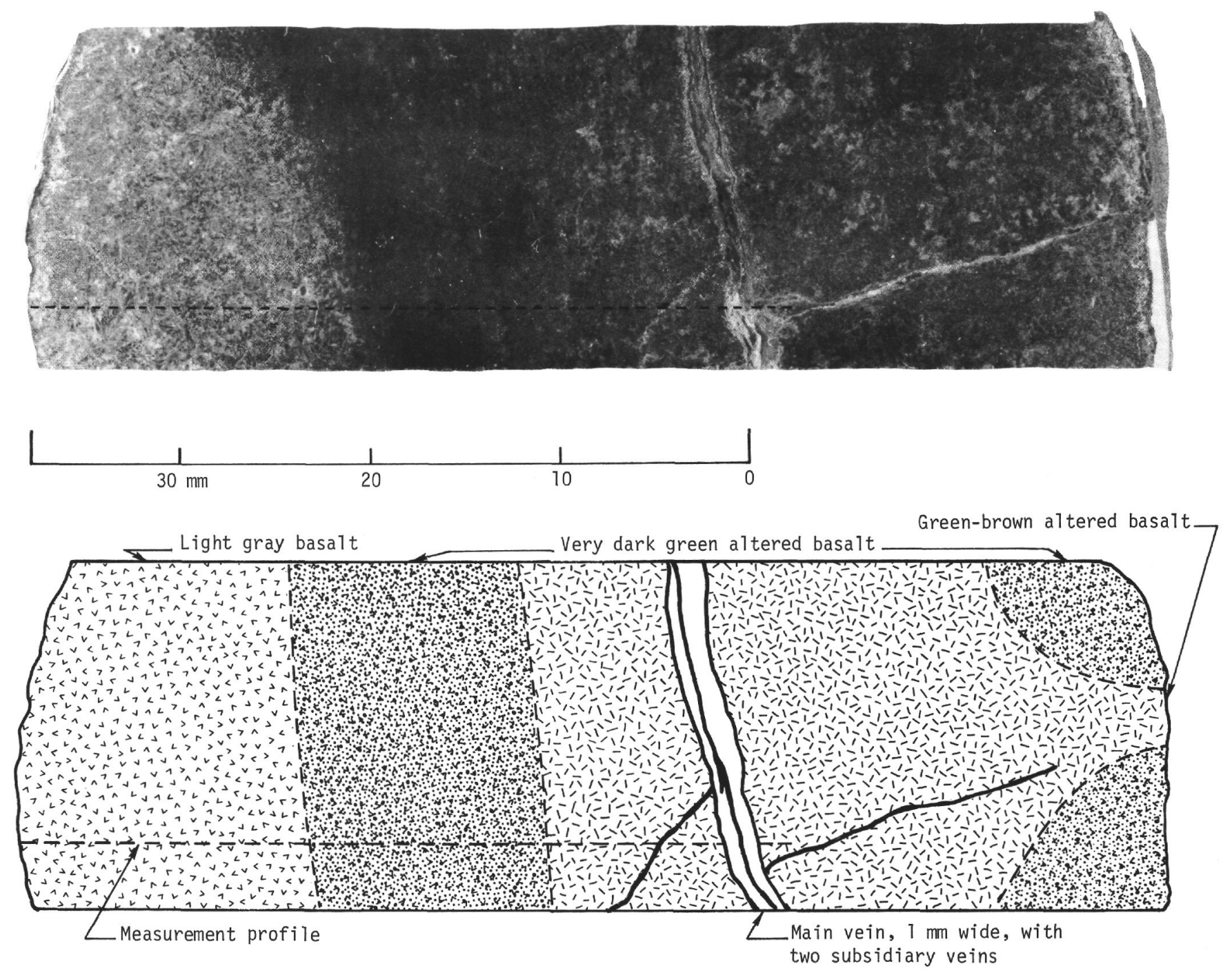

Figure 22. Polished section of split minicore 319A-2-1, 140-143 cm, dashed line indicates profile of Figure 23.

as two distinct size generations. High temperature oxidation of titanomagnetite, with low titanium magnetite containing ilmenite lamella as products, is rare, even in the interior of flows which provide a favorable environment in subaerial conditions. Low temperature oxidation is widespread, affecting all the pillow material and parts of the massive flow interiors. The low temperature oxidation features, volume change cracks, color lightening, reflectivity increase, and replacement of titanomagnetite by a gray phase with very fine grain size are known in subaerial lavas as ambient temperature (weathering) products. In the deep ocean environment the analog of weathering is halmyrolysis, and these features are clearly halmyrolytic alteration features. A sequence of these alteration features is correlated with degree of cation deficiency, $z$, which ranges from zero in some of the massive basalts to 0.96 , with many values, especially in the pillow basalts, in excess of 0.6 . The deep ocean environment is, for the alteration of basaltic titanomagnetite, closer to the intrusive environment than the subaerial extrusive environment, which is characterized by common deuteric oxidation. A consequence of the low degree of deuteric oxidation of the Nazca plate and other submarine lavas is that easily oxidized, high titanium, titanomagnetite is available abundantly for alteration by the halmyrolytic or hydrothermal alteration processes.

The widespread halmyrolitic alteration of titanomagnetite in submarine lavas is of more than mineralogical interest. In another chapter (Ade-Hall et al., Rock Magnetism of Basalts, this volume), we show that cation deficiency, $z$, of titanomagnetite is correlated strongly with variation in most magnetic properties. Thus NRM intensity, saturation magnetization, and initial susceptibility decrease with increasing $z$, while Curie point and mean demagnetizing field increase with increasing $z$. While the physical nature of the relationship between $z$ and these magnetic properties is not fully explained, the geophysical significance of the relationship seems clear; wherever oceanic layer 2 has experienced extensive halmyrolysis, natural magnetization, and the associated linear magnetic anomaly pattern will be strongly reduced in amplitude. Extensive halmyrolysis could be the outcome of either prolonged seawater circulation, where 
TABLE 3

Opaque Mineralogy and Degree of Cation Deficiency in the Vicinity of a Vein in Massive Basalt from Site $319^{\mathrm{a}}$

\begin{tabular}{|c|c|c|c|}
\hline Dis & $\begin{array}{l}\text { stance From } \\
\text { Tein }(\mathrm{mm}) \\
\text { Type of Basalt }\end{array}$ & Opaque Mineralogy & $\begin{array}{c}\text { Cation Deficiency } \mathrm{b} \\
\text { (Fraction } z \text {, of } \mathrm{Fe}^{2+} \text { replaced by } \mathrm{Fe}^{3+} \text { ) }\end{array}$ \\
\hline 1 & Green-brown & $\begin{array}{l}\text { Gray magnetite with volume change cracks, many } \\
\text { grained deuterically oxidized to classes } 2 \text { or } 3 \text {; } \\
\text { magnetite in some exsolved grains adjacent to the } \\
\text { vein replaced by a pebbly textured phase; hematite } \\
\text { or iron hydroxide masses present; silicates uni- } \\
\text { formly orange stained }\end{array}$ & 0.96 \\
\hline 3 & & $\begin{array}{l}\text { Gray-brown class } 1 \text { magnetite with volume change } \\
\text { cracks, sometimes hematite or iron hydroxide al- } \\
\text { teration adjacent to cracks; widespread orange } \\
\text { staining of silicates }\end{array}$ & 0.72 \\
\hline 10 & $\begin{array}{l}\text { Very dark } \\
\text { green }\end{array}$ & $\begin{array}{l}\text { Light brown class } 1 \text { magnetite; volume change } \\
\text { cracks with associated slight alteration of magnetite; } \\
\text { some fresh ilmenite }\end{array}$ & 0.65 \\
\hline 16 & $\begin{array}{c}\text { altered } \\
\text { basalt }\end{array}$ & $\begin{array}{l}\text { Light brown class } 1 \text { magnetite; occasional orange } \\
\text { staining of silicates; volume change cracks with } \\
\text { associated slight alteration of magnetite }\end{array}$ & 0.61 \\
\hline 23.5 & & $\begin{array}{l}\text { Uniformly light brown class } 1 \text { magnetite with some } \\
\text { volume change cracks }\end{array}$ & 0.60 \\
\hline 30 & $\begin{array}{l}\text { Light gray } \\
\text { basalt }\end{array}$ & $\begin{array}{l}\text { Uniformly light brown class } 1 \text { magnetite with some } \\
\text { volume change cracks }\end{array}$ & 0.41 \\
\hline 36 & & $\begin{array}{l}\text { Uniformly light brown class } 1 \text { magnetite with some } \\
\text { volume change cracks }\end{array}$ & 0.50 \\
\hline
\end{tabular}

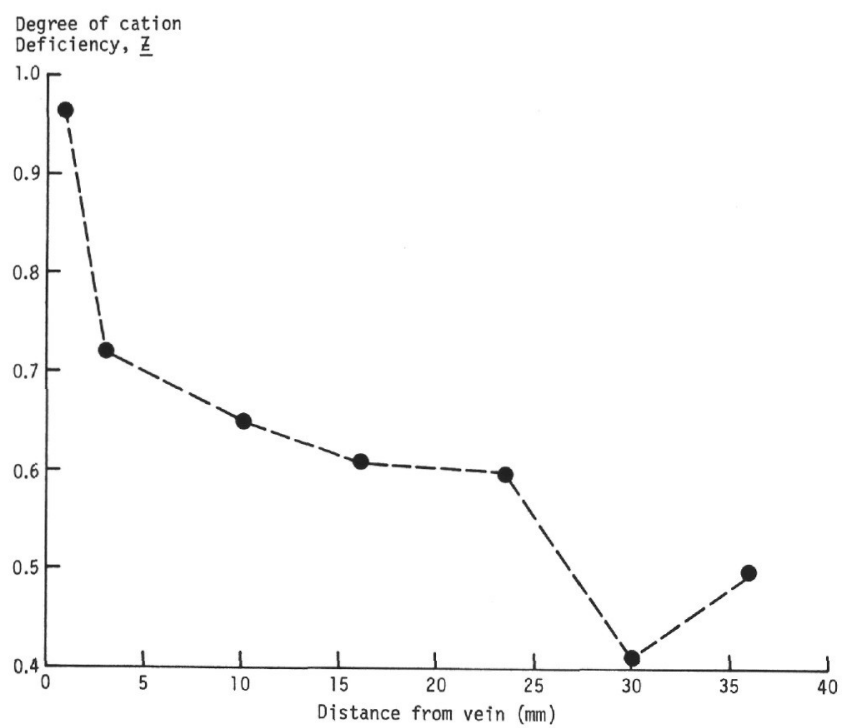

Figure 23. Variation of cation deficiency of titanomagnetite adjacent to the vein cutting the split minicore shown in Figure 22.

its extent would be a function of crustal age, or the local presence of an abundance of permeable rock formations, such as pillow lava sequences. The former mechanism is advocated as an explanation for the sharply defined change in magnetic anomaly amplitude where 6-m.y.-old East Pacific Rise crust abuts against 16-m.y.-
TABLE 4

Primary and Secondary Sulfide Contents of Hole 319A Basalts

\begin{tabular}{lccc}
\hline $\begin{array}{c}\text { Sample } \\
\text { (Interval in cm) }\end{array}$ & $\begin{array}{c}\text { Total Area } \\
\text { Examined } \\
\left(10^{6} \mu^{2}\right)\end{array}$ & $\begin{array}{c}\text { Primary } \\
\text { Sulfide } \\
\left(\times 10^{3} \%\right)\end{array}$ & $\begin{array}{c}\text { Secondary } \\
\text { Sulfide } \\
\left(\times 10^{3} \%\right)\end{array}$ \\
\hline $1-1,14-17(1)$ & 2.8 & 3.3 & 0 \\
1-1, 39-42 (2) & 2.5 & 1.6 & 0 \\
2-1, 106-109 (1) & 5.0 & 15.0 & 0 \\
2-1, 140-143 & 1.7 & 2.9 & 12 \\
(split minicore) & & & \\
2-1, 146-149(2) & 5.2 & 9.9 & 290 \\
3-2, 108-111(1) & 5.2 & 0.42 & 0 \\
3-5, 81-84 (2) & 5.0 & 200.0 & 0 \\
4-1, 133-136(1) & 1.4 & 240.0 & 0.51 \\
$5-1,87-90(2)$ & 1.2 & 220.0 & 0 \\
6-1, 142-145(2) & 1.5 & 1.9 & 0 \\
$7-1,40-43(1)$ & 1.3 & 7.8 & 0 \\
\hline
\end{tabular}

old Galapagos Rise crust on both flanks of the East Pacific Rise (Ade-Hall, Underway Surveys, this volume).

The most valuable extension of this study will be to quantify the indicators of degree of halmyrolytic alteration, particularly by measurement of volume change cracking development and color and reflectivity change. The aim will be to estimate the degree of cation deficiency of a titanomagnetite from optical examination alone.

A significant geophysical result, arising from this study of the opaque phases and concerned with the development of new crustal plates at a ridge crest, is the 
absence of evidence for a hydrothermal alteration history for the basement basalts at any of the three Nazca plate sites. If this proves generally to be the case and if hydrothermal circulation is responsible for the removal of most of the geothermal heat at ridge crests, the area over which hot water upwells must be significantly smaller than the area over which downward flow of cold water occurs. Extension of the opaque petrographic and rock magnetic tests made on the Leg 34 basalts to material from other DSDP sites will show if an absence of a hydrothermal alteration history is a general property of uppermost layer 2 .

\section{ACKNOWLEDGMENTS}

Dennis Bohrer and Wally Charm prepared the polished surfaces for shipboard examination. Jeff Clarke made the Curie point measurements on Sample 319A-2-1,140-143 cm. Monika Michaelis typed the manuscript, which was read critically by Osama Abdel-Aal, who also checked some mineralogical determinations by microscope and microprobe methods. The authors owe their thanks to all of these generous helpers.

\section{REFERENCES}

Ade-Hall, J.M., Khan, M.A., and Wilson, R.L., 1968. A detailed opaque petrological and magnetic investigation of a single Tertiary lava from Skye Scotland: Part I: irontitanium oxide petrology: Geophys. J., v. 16, p. 374-388.

Ade-Hall, J.M., Palmer, H.C., and Hubbard, T.P., 1971. The magnetic and opaque petrological response of basalts to regional hydrothermal alteration: Geophys. J., v. 24, p. 137-174.

Ade-Hall, J.M., 1974. The opaque mineralogy of basalts from DSDP Leg 26. In Luyendyk, B.P. and Davies, T., Initial Reports of the Deep Sea Drilling Project, Volume 26: Washington (U.S. Government Printing Office), p. 533-539.

Creer, K.M. and Ibbetson, J.D., 1970. Electron microprobe analyses and magnetic properties of non-stoichiometric titanomagnetites in basaltic rocks: Geophys. J., v. 21, p. 485-511.

Dalrymple, G.B. and Moore, J.G., 1968. Argon 40: Excess in submarine pillow basalt from Kilauea volcano, Hawaii: Science, v. 161, p. 1132-1135.

Grommé, C.S., Wright, T.L., and Peck, D.L., 1969. Magnetic properties and oxidation of iron-titanium oxides in Alae and Makaopuhi lava lakes, Hawaii: J. Geophys. Res., v. 74 , p. $5277-5294$.

Hart, R.A., 1973. A model for chemical exchange in the basalt-seawater system of oceanic layer II: Canadian J. Earth. Sci., v. 10, p. 799-816.

Hauptman, Z., 1974. High temperature oxidation, range of non-stoichiometry and Curie point variation of cation deficient titanomagnetite $\mathrm{Fe}_{24} \mathrm{Ti}_{06} \mathrm{O}_{4}$ : Geophys. J., v. 38, p. 29-47.

Irving, E., Park, J.K., Haggerty, S.E., Aumento, F., and Loncarevic, B., 1970. Magnetism and opaque mineralogy of basalts from the Mid-Atlantic Ridge at $45^{\circ} \mathrm{N}$ : Nature, v. 228, p. 974-976.

Johnson, H.P. and Merrill, R.T., 1973. Low temperature oxidation of a titanomagnetite and the implications for paleomagnetism: J. Geophys. Res., v. 78, p. 4938-4949.

Kitazawa, K. and Ade-Hall, J.M., 1972. Magnetic and opaque mineralogical properties of basalts from DSDP Legs II, III, V and VI: Am. Geoph. Union Trans., v. 53, p. 974 (abstract).

Laughton, A.S., Berggren, W.A., et al., 1972. Initial Reports of the Deep Sea Drilling Project, Volume 12: Washington (U.S. Government Printing Office).

Lindsley, D.H., 1962. Ann. Rept.: Director Geophys. Lab, Carnegie Inst. gie Inst. 1965. Ann. Rept.: Director Geophys. Lab., Carne-

Ryall, P.J.C. and Ade-Hall, J.M., in preparation. Laboratory induced self-reversal of TRM in pillow basalts.

Sato, M. and Wright, T.L., 1966. Oxygen fugacities directly measured in magmatic gases: Science, v. 153, p. 1103-1105.

Wilson, R.L., Haggerty, S.E., and Watkins, N.D., 1968. Variation of paleomagnetic stability and other parameters in a vertical traverse of a single Icelandic lava: Geophys. J., v. 16, p. $79-96$. 